\title{
低サイクル片振り引張疲水に扣ける鋼材の 塑性ひずみ挙動に及ぼす切欠を効果
}

\author{
正員 永 井 欣 一* 正員 岩 田 光 正 $^{*}$ \\ 正員 西 村 誠 二**
}

Effect of Notch on Behaviors of Plastic Strain on Steels Subjected

to Low Cycle Pulsating Tension

By Kin-ichi Nagai, Member Mitsumasa Iwata, Member

Seiji Nishimura, Member

\section{Summary}

Low cycle fatigue tests were carried out for specimens with circular hole and quasi-elliptical hole under constant load pulsating tension. The materials used are mild steel (SM 41) and quenched and tempered high tensile strength steel (HT 60). The development of plastic strain around a circular hole and a quasi-elliptical hole was experimentally analyzed by the Moiré method at successive stages of fatigue, and the following characteristics were clarified concerning the plastic behavior in the specimens under low cycle fatigue.

The following three types of fracture were confirmed in the low cycle fatigue test for two kinds of "steels.

Type-A : A ductile fracture occurs after the necking of the whole part of the net section.

Type-B : A fatigue crack initiates after the necking solely at the notch root and strain at the tip of crack increases as it extends.

Type-C : A fatigue crack initiates and propagates without a little strain increase at the tip of the crack.

In the case of type- $\mathrm{A}$ fracture the maximum equivalent strain at the fracture position becomes from 50 to 60 percent, while in type-C fracture it becomes below 20 percent at the stage of crack initiation. In the case of type- $B$ fracture the maximum equivalent strain at the fracture position lies between type- $\mathrm{A}$ and type- $\mathrm{C}$ values. These strain values are irrespective of materials, size and shape of specimens, and the number of cycles to cause fracture of type- $\mathrm{A}$ or crack initiation of type-B and $\mathrm{C}$.

The following relation exists, in the case of type-A fracture, without concern to materials, size and shape of specimens,

where $\Delta \bar{\varepsilon}_{m}$ is the steady state creep rate,

$$
\Delta \bar{\varepsilon}_{m} \cdot N_{f}=\bar{\varepsilon}_{0} / 2
$$

$N_{f}$ is the number of cycles to cause fracture of type-A or crack initiation of type-B and C,

$\bar{\varepsilon}_{0}$ is the equivalent plastic strain at fracture in simple tension.

In the case of type-C fracture, however, the formula no longer holds good and the critical number of cycles to cause fracture, which indicates that the relation between $\Delta \bar{\varepsilon}_{m}$ and $N_{f}$ deviates from the formula, is larger in SM 41 than in HT 60.

* 広島大学工学部

** 広島大学大学院 


\section{1 鍺 言}

船体梅造不連続部に発生する疲れき裂は低サイクル疲れによるものであることが多く，応力集中を生じる個所 で繰返し塑性ひずみを受计損傷を起こす可能性がある。したがつて構造物の設計に有用な低サイクル疲れの研究 としては平滑材よりはむしろ切欠き材による疲れ特性が局部ひずみの点から検討される必要がある。この観点か ら著者らのひとりは前報1)において軟鋼および $60 \mathrm{~kg} / \mathrm{mm}^{2}$ 級調質形高張力鋼の平滑試験片および弾性応力集中 率 2.16 の円孔切欠き試験片により低サイクル疲机試験を行なつて, 疲れき裂発生までの荷重繰返しの各段階沉 路㳯る局部ひずみをモアレ法によつて解析した。その結果, 破断点のひずみはサイクリック・クリープ現象を呈 し，その定クリープ速度と破断繰返し数の間には直線累積の法則が成立することを明らかにした。

本研究ではさらに弾性応力集中率の大きい円孔拈よび準棈円孔切欠き試験片により同様な実験を行ない，疲れ き裂登生後のひずみ解析も行なつて直線累積の法則について検討を加えた。

\section{2 実 験 方 法}

使用した鋼材は板厚 $10 \mathrm{~mm}$ の軟鋼 (SM 41) 抢よび $60 \mathrm{~kg} / \mathrm{mm}^{2}$ 級調質形高張力鋼 (HT 60) で，穴の機械的 性質㧍よびミルシートから引用した化学組成を Table 1 と示す。これらの鋼材から Fig. 1 抢よび Fig. 2 と示 す小形試験片および大形試験片を採取した。本実験では試験片の形状とくに弾性応力集中率 $\alpha$ の影響を調べる ため小形試験片についてはFig.1 (a) および (b) に示す準棈円孔切久き試験片および円孔切久き試験片の二種 類を用意した。な扮前者の弾性応力集中率 ${ }^{2)} \alpha$ は 3.10, 後者 ${ }^{2}$ のそれは 2.42 である。大形試験片については Fig. 2 に示すよよう小形円孔切欠き試駼片と相似にし，弾性応力集中率は 2.42 である。

小形試験片に対しては容量 2 トンの軸荷重引張圧縮疲れ試験機により繰返し速度 $65 \mathrm{cpm}$ で, 大形試験片に対し ては容量 200 トンの自動負荷制御装置付油圧万能試験機により繰返し速度約 $1 \mathrm{cpm}$ でそれぞれ荷重制御片振り引

Table 1 Mechanical properties and chemical compositions of materials

\begin{tabular}{c|c|c|c|c|c|c|c|c|c}
\hline Material & $\begin{array}{c}\text { Yield point } \\
\mathrm{kg} / \mathrm{mm}^{2}\end{array}$ & $\begin{array}{c}\text { Tensile } \\
\text { strength } \\
\mathrm{kg} / \mathrm{mm}^{2}\end{array}$ & $\begin{array}{c}\text { Elongation } \\
\%\end{array}$ & $\begin{array}{c}\mathrm{C} \\
\times 100\end{array}$ & $\begin{array}{c}\mathrm{Si} \\
\times 100\end{array}$ & $\begin{array}{c}\mathrm{M} \\
\times 100\end{array}$ & $\begin{array}{c}\mathrm{P} \\
\times 1000\end{array}$ & $\begin{array}{c}\mathrm{S} \\
\times 1000\end{array}$ & $\begin{array}{c}\mathrm{V} \\
\times 1000\end{array}$ \\
\hline $\mathrm{SM} 41$ & 26.6 & 44.5 & 32.6 & $<20$ & $<35$ & $60 \sim 120$ & 13 & 25 & - \\
$\mathrm{HT} 60$ & $\begin{array}{c}59.9 \\
(58)\end{array}$ & $\begin{array}{c}69.7 \\
(68)\end{array}$ & $\begin{array}{c}23.1 \\
(26)\end{array}$ & 16 & 24 & 118 & 14 & 8 & 6 \\
\hline
\end{tabular}

for SM $41 \cdots \cdots$ JIS No. 1 (G. L. $=200 \mathrm{~mm}$ )

for HT $60 \ldots . . . J I S$ No. 5 (G. L. $=50 \mathrm{~mm}$ )

( ) …........from Mill Sheet

\section{Rolling direction}

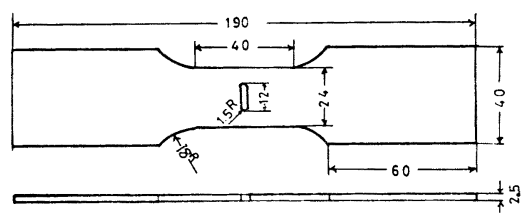

(a) Small specimen with quasi-elliptical hole
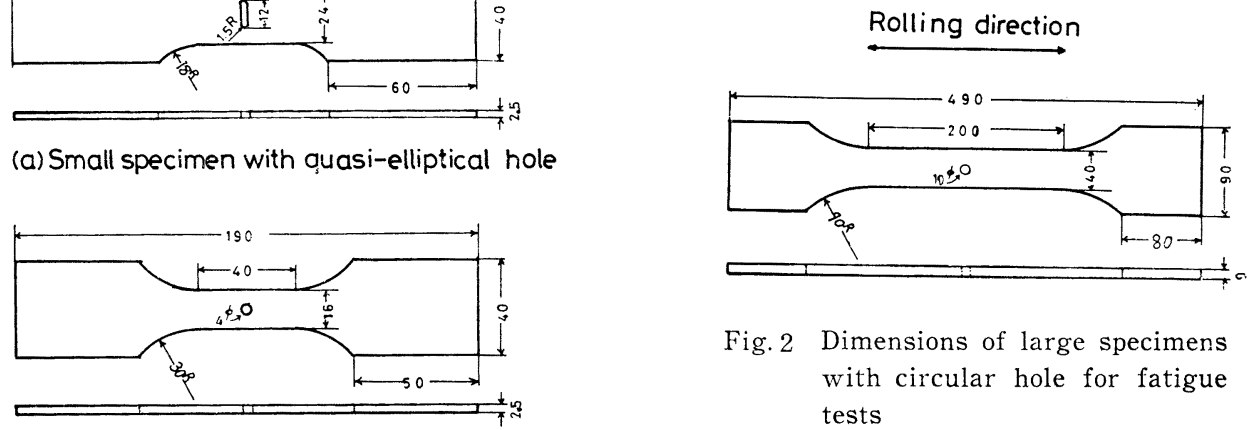

Fig. 2 Dimensions of large specimens with circular hole for fatigue tests

(b)Small specimen with circular hole

Fig. 1 Dimensions of small specimens for fatigue tests 
張疲机試験を行なつた。なお，小形試 験片の下限荷重を 0 トン, 大形試験片 のそれを 1.5 トン一定とし, 上限荷重 を種々変えた。

各試験片の局部ひずみの測定はじゅ ららいどおりモアレ法に上つて行なお， れた。すなわちあらかじめ写真食刻法 によつて直交格子（150 们インチ）を 焼付汁大試験片を用意し, 繰返し負荷 の各段階において变形した格子を写真 撮影し, rotational mismatching 法 とよりひずみ分布を解析した。疲祘㰻 験の各段階における写真撮影は除荷し た状態で行なわれた。降伏点を越えて 負荷したときの弾性ひずみは塑性ひず 及纪比べて無視できるので, 除荷時の 塑性ひず友を負荷時の全ひず友々及低 してさしつかえない。

\section{3 実 験 結 果}

\section{1 ひずみ分布}

各試験片の片振り引張疲机試験によ いて局部ひずみをモアレ縞の解析にょ つ七求为, 最小断面に敊许る有効ひず 又 $\bar{\varepsilon}$ の進行状態をSM 41 と HT 60 に ついて比較した。その結果を小形準楕 円孔，小形円孔および大形円孔試験片 について Fig. 3, Fig. 4 抢よび Fig. 5 汇气礼ぞれ示す。図中の $2 S_{a}$ は最小断 面に打计る公称沁力で表わした応力振 幅の 2 倍を示し， $N_{f}$ はき裂発生または 破断時の繰返し数を示す。なおこ机に

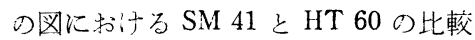
はそれぞれの鋼材の引張強さに対する 応力振幅の比がほほ注等しい試験片にこ いて行なわれた。SM 41 ではいずれの 試験片に打いてもひずみは広い範囲に わたつて繰返し数の增加とともに增大 するのに対し，HT 60 ではとくに切 欠き底で局部的にひずみが集中して增 大し，前報に扎いて述べたように高張 力鋼はひず集中を生じやすいという 特徵がらかがえる。

またこれらの図においてびず增加 の傾向をみると，第 1 サイクルで大き な塑性ひずみを生じその後 1 サイクル
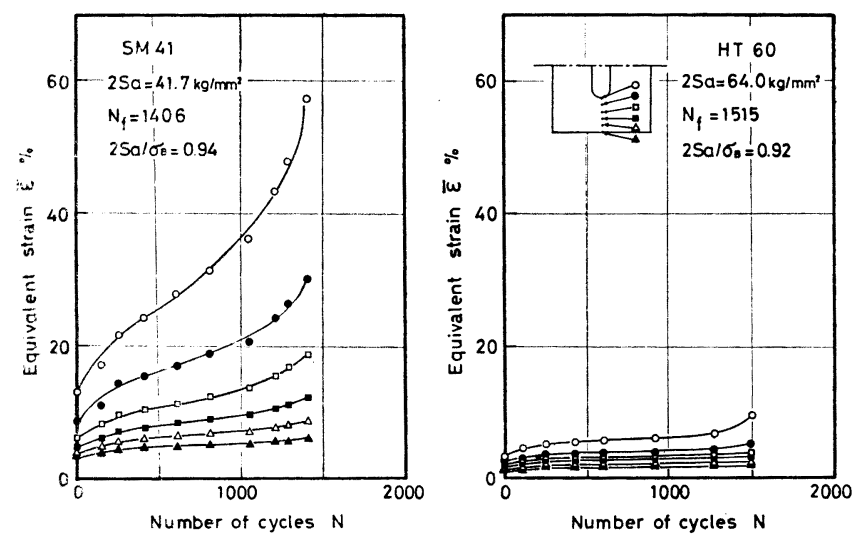

Fig. 3 Variations of equivalent strain at each position of net section of small specimens with quasi-elliptical hole under pulsating tension
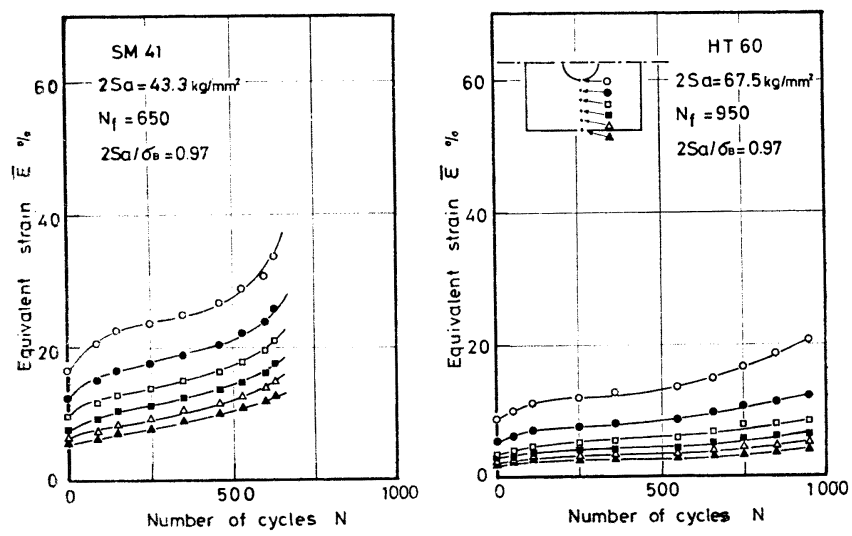

Fig. 4 Variations of equivalent strain at each position of net section of small specimens with circular hole under pulsating tension
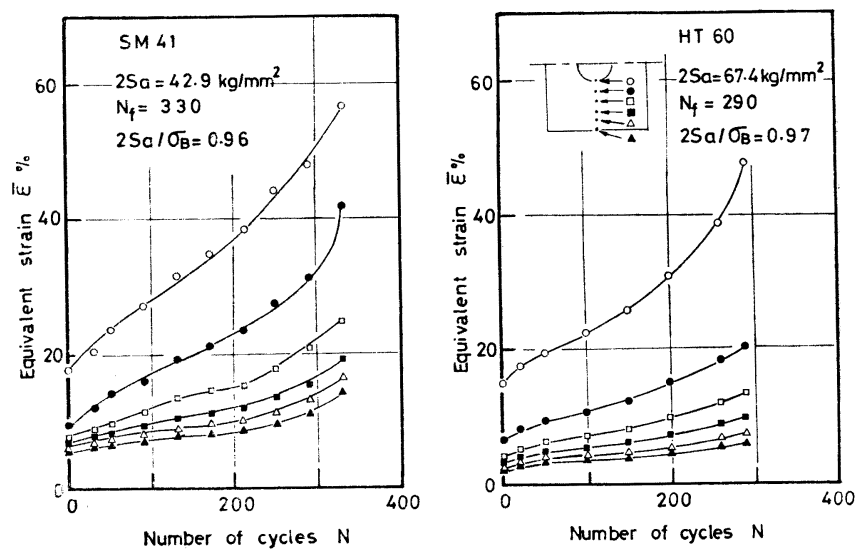

Fig. 5 Variations of equivalent strain at each position of net section of large specimens with circular, hole under pulsating tension 


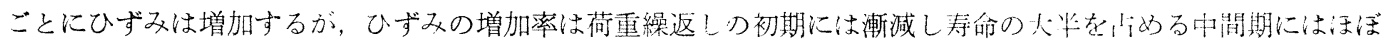

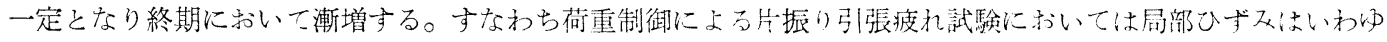
るサイクリック・クリープ現象を呈している。

\section{2 切欠き底におけるひずみの変化}

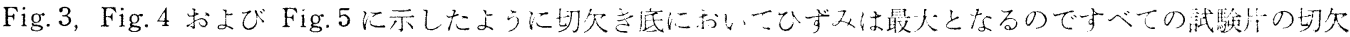
き底にお汁る有効ひずみを繰返し数汇対して図示する之Fig.6－Fig. 11 のようになる。

この低サイクル片振り引張疲れ試験汅おいて各試験片が最終破断にいたる状沉を钼察した綃橗，破壞過程とし て次の三つの形式が観察された。その 1 例をPhoto. 1 のモアレ縞写真で示与。これによると破填形式には

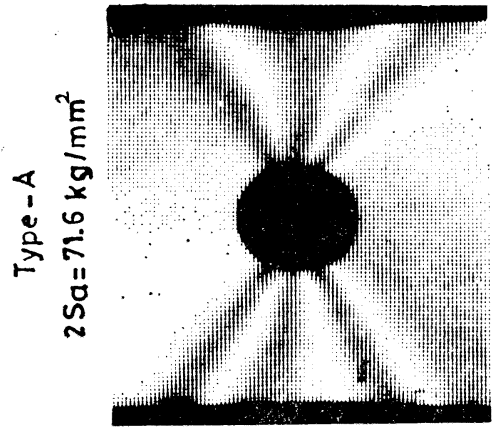

$N=1$

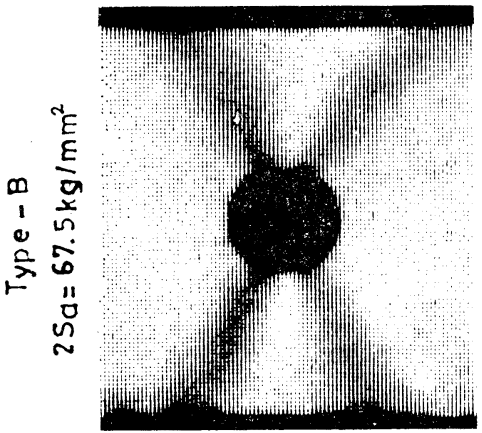

$N=1$

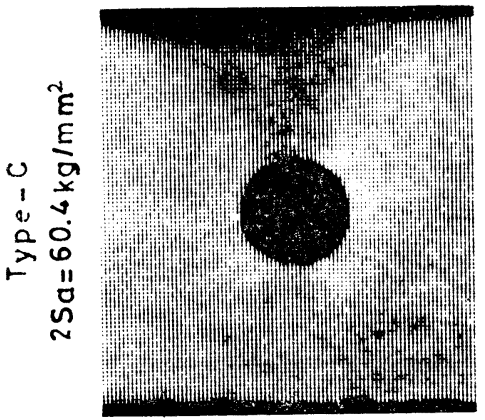

$N=6000$

before crack initiation

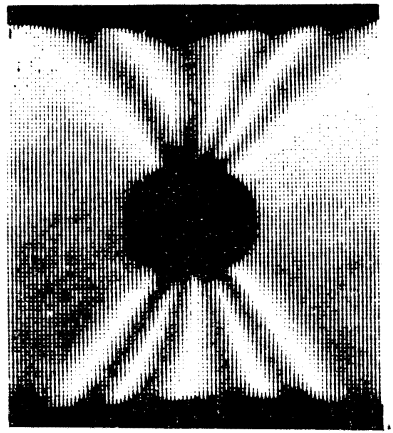

$N=220$

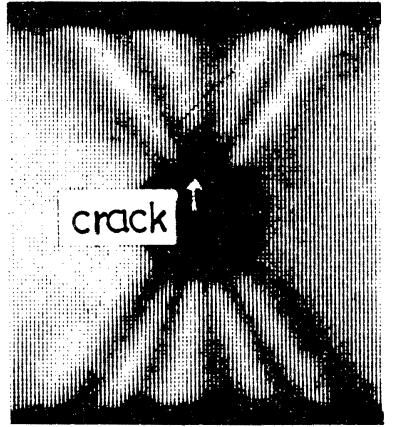

$N=1500$

crack initiation

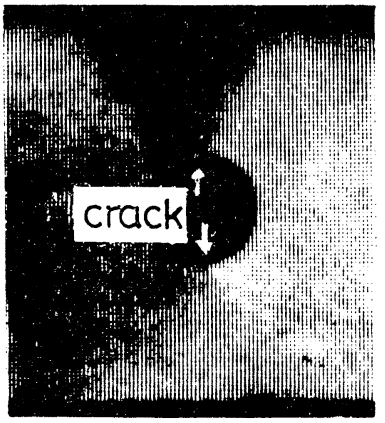

$N=6500$

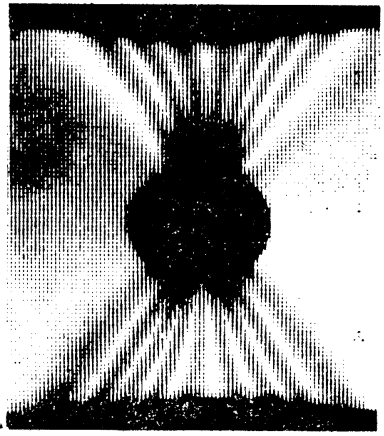

$N=360$ just before fracture

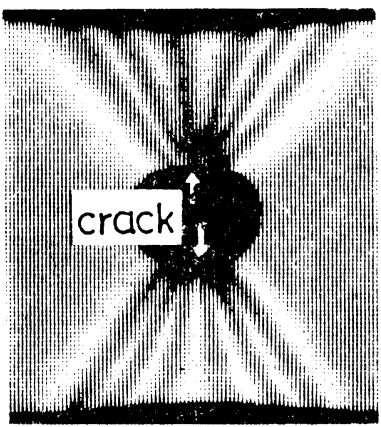

$N=1900$

just before fracture

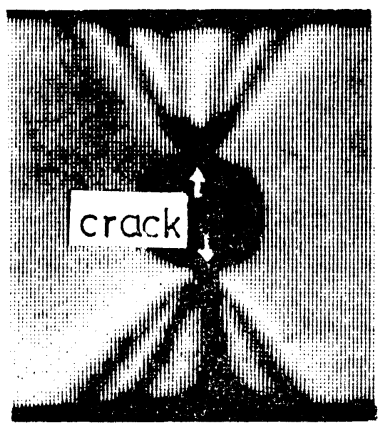

$N=6970$ crack initiation just before fracture

Photo. 1 Moiré fringes of three typical modes of fracture under pulsating tension (HT 60) Type-A : Strain increases rapidly without any crack initiation

Type-B : Initiation of a crack occurs and strain increases with the slight extention of the crack

Type-C : A crack initiates and extends without a little increase in strain 


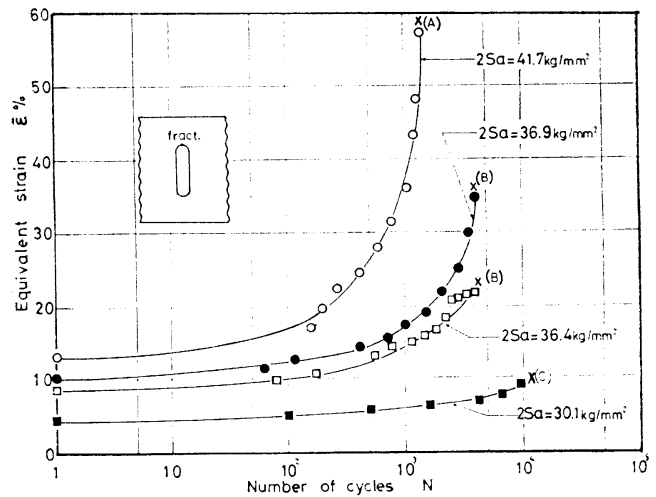

Fig. 6 Variations of equivalent strain at fracture position of small specimens (SM 41) with quasi-elliptical hole under various pulsating tensile stress

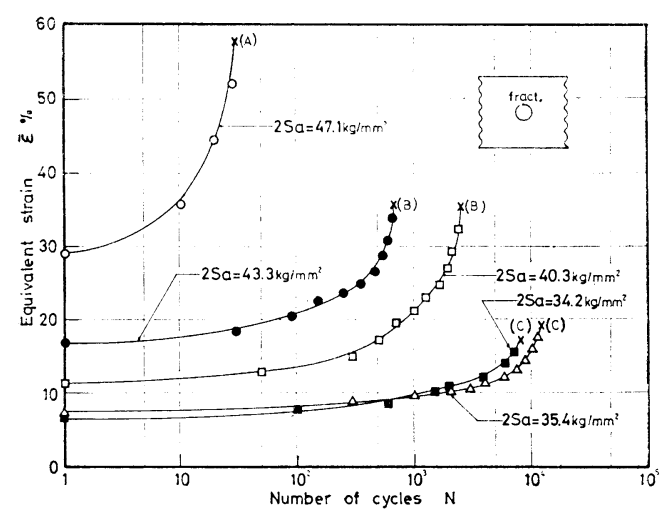

Fig. 8 Variations of equivalent strain at fracture position of small specimens (SM 41) with circular hole under various pulsating tensile stress

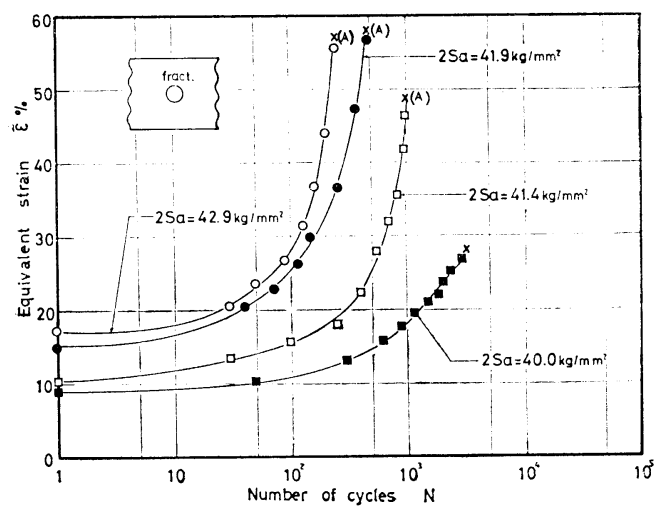

Fig. 10 Variations of equivalent strain at fracture position of large specimens (SM 41) with circular hole under various pulsating tensile stress

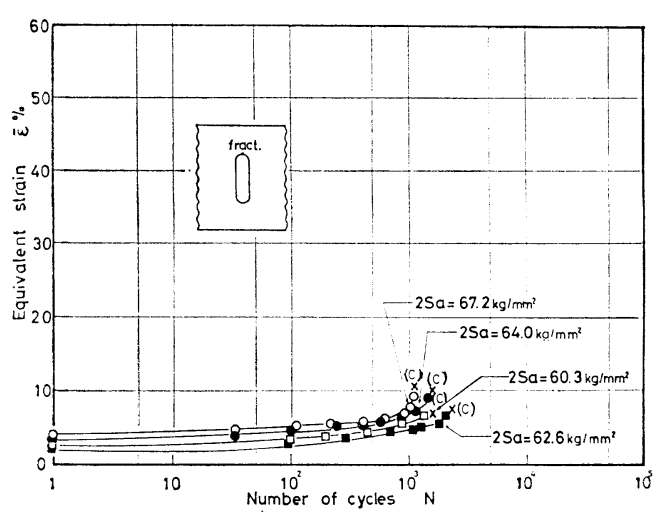

Fig. 7 Variations of equivalent strain at fracture position of small specimens (HT $60)$ with quasi-elliptical hole under various pulsating tensile stress

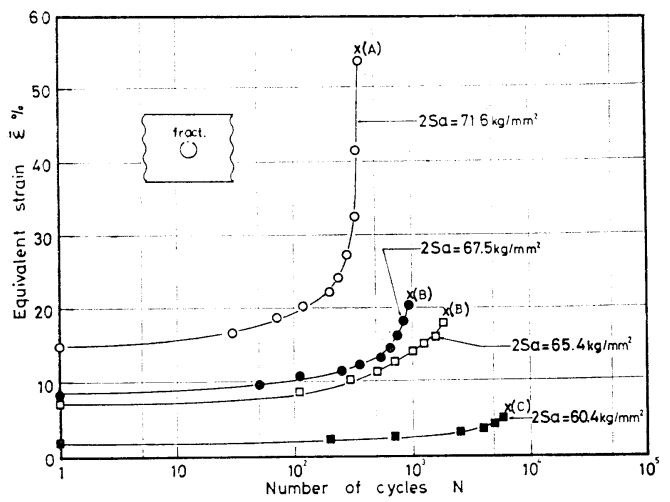

Fig. 9 Variations of equivalent strain at fracture position of small specimens (HT $60)$ with circular hole under various pulsating tensile stress

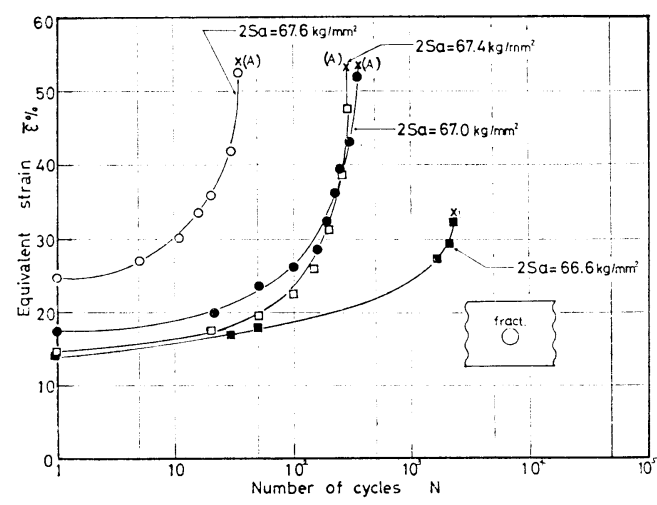

Fig. 11 Variations of equivalent strain at fracture position of large specimens (HT 60 ) with circular hole under various pulsating tensile stress 
（A）試騃片の最小断面全体にネたりかなりの局部収縮を生じたのち静的引張りにおける破壊形式と類似な延 性破壞を起こ守場合

（B）切欠き底で局部収縮を生じて疲れき裂を発生するが，き裂はほとんど伝播しないでひずみが堌加し延性 破壞を起こす場合

（C）ほとんど局部収縮を生じないで切欠き底において疲れき裂が発生し，ひずみの增加を伴ならことなくき 裂が伝播して, 最終的には断面積の減少により応力が増加して延性破壊を起こす場合

ぶある。以後この三つの形式をそれぞれA形、B形掞よびC形の破壞と呼ぶこととし，Fig. 6 から Fig. 11 の各 曲線の終点にこの破壊の形式を付記してある。なおこれらの図において $(\mathrm{A})$ を付した×印はき裂の発生，伝播を 伴ならことなく延性破壊を起こした時の繰返し数および有效ひずみを示し，（B）扣よび(C)を付したメ印はいず れも切欠き底におけるき裂発生時のそれらを示す。たとえば Fig. 6 の SM 41 小形準棈円孔試験片の場合 $2 S_{a}=$ $41.7 \mathrm{~kg} / \mathrm{mm}^{2}$ の試験片は惩性破壞（A 形）を起こすが， $2 S_{a}=36.9 \mathrm{~kg} / \mathrm{mm}^{2}$ および $2 S_{a}=36.4 \mathrm{~kg} / \mathrm{mm}^{2}$ では 波れき裂の発生をみて破壊（B形）し，2 $S_{a}=30.1 \mathrm{~kg} / \mathrm{mm}^{2}$ ではき裂が発生，伝播して破壞（C形）を生じた。 また Fig. 8 および Fig. 9 に示す SM 41 および HT 60 小形円孔試験片においても上記 3 種類の破壞形式が認 められるが, Fig. 7 の HT 60 小形準棈円孔試験片ではすべてC 形の破壊を起こしている。Fig. 10 拉よび Fig. 11 に示す大形円孔試験片の場 合には繰返し速度が抢そくき裂発生後試験を中止したのでB形破壞とC形破壞の 区別はできなかつた。

またこれらの罒においてA形破壊を起こした試験片では最初のサイクルによる塑性ひずみは種々異なつている が，破断時の有効ひずみは試験片の形状，寸法および材質によらずほぼ 50〜 60\% と一定值に達し延性破壊を起 こすことが認められ，他のB形女るいはC形の破壞と区別される。そしてB形およびC形破壞を生じた試験片の 切欠き底におけるき裂発生時のひずみはB形では 20 拉％になるが，C形では $20 \%$ 以下になつている。

\section{3 き裂先端のひずみ}

この低サイクル疲れ試験における試験片の破壊形式は上述のごとくA形，B形およびC形に分類される。そこ でB形およでC形の破壊を生じた試験片については Fig. 6〜Fig. 11 に示したき裂発生までのひずみにひきつづ いてさらにき裂発生後のひずみの变化を追跡した。Fig. 12 および Fig. 13 は小形準棈円孔および小形円孔試験 片に生じた疲れき裂の長さとき裂先端における有効ひずみとの関係を示す。同図によると応力振幅 $2 S_{a}$ の高い 場合はいずれの試験片においてもき裂発生時の有効ひずみは大きく，き裂長さのわずかな増加に伴なつてき裂先 端のひずみが急速に増加し B 形破壊を起こす。他方, 比較的低い応力振幅においては疲れき裂発生時の有効ひず
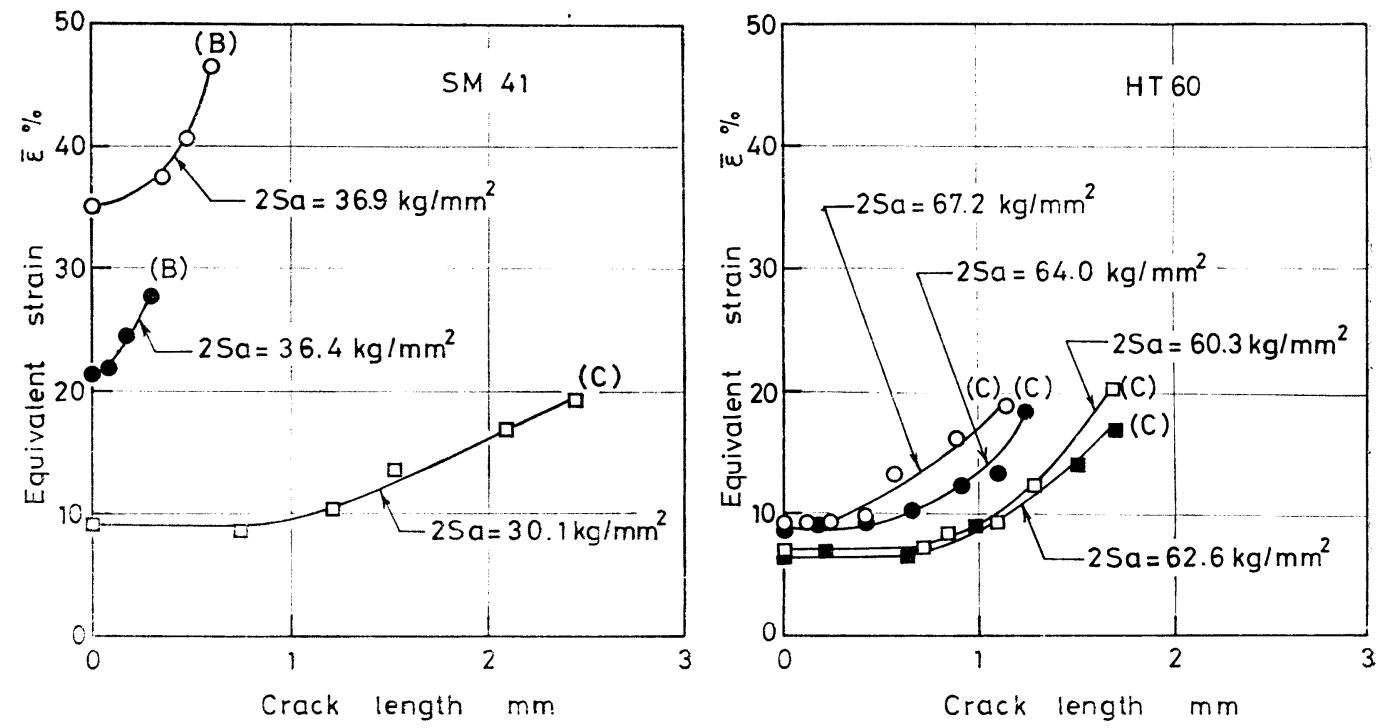

Fig. 12 Relation between equivalent strain at the tip of crack and crack length of small specimens with quasi-elliptical hole 

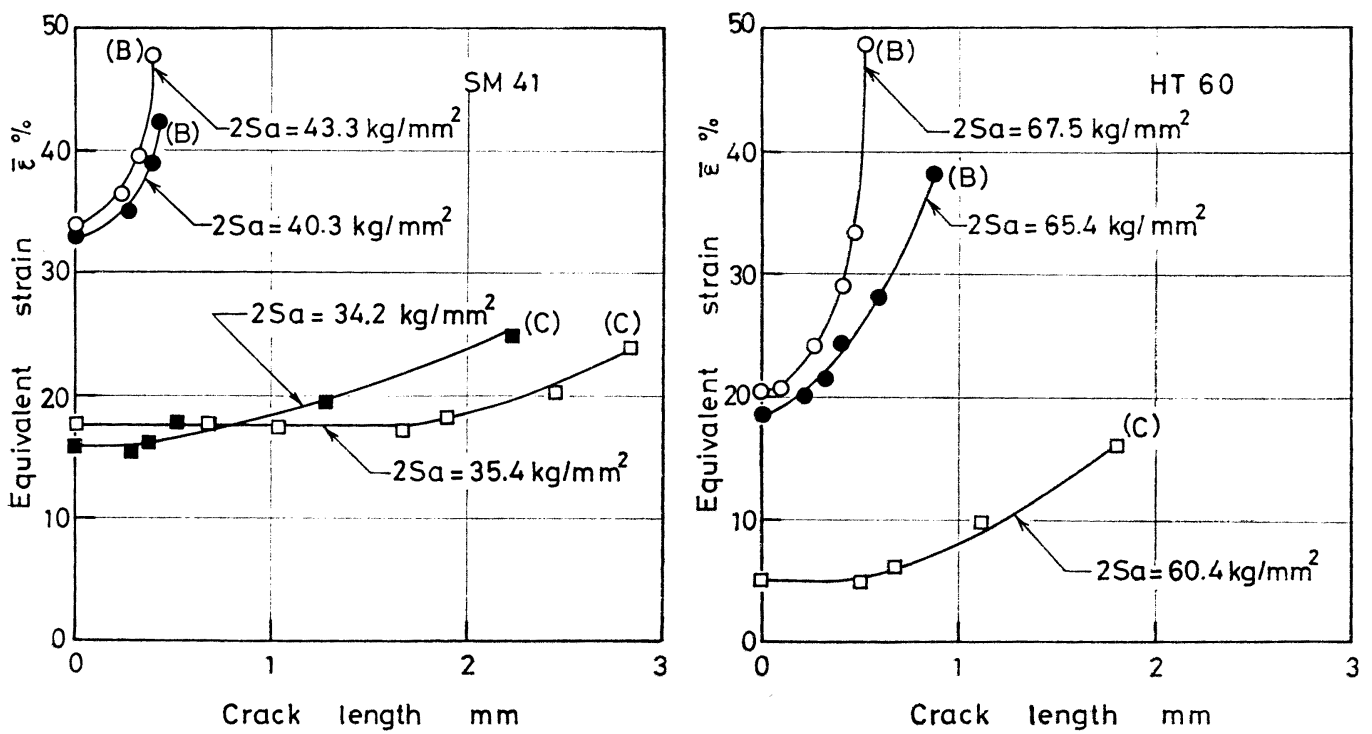

Fig. 13 Relation between equivalent strain at the tip of crack and crack length of small specimens with circular hole

みは小さく疲れき裂長さが SM 41 では $0.3 \sim 1.6 \mathrm{~mm}, \mathrm{HT} 60$ では $0.2 \sim 0.7 \mathrm{~mm}$ に達するまではき裂先端 のひずみの增加は認められず，その後のひずみ增加もゆるやかでC形破壊となる。すなわち疲れき裂の発生，伝 播を伴なら破壞に抏いては伝播の過程でき裂発生直後からひずみの増加を伴なう場合と伝播過程のある期間ひず みは增加しない場合とが存在することが明らかになつた。

以上本節に打ける局部ひずみ解析の結果から荷重制御低サイクル片振り引張疲れにおける破壞形式は静的引張 りにみられる破壞形式に似た延性破壊となるA形, 高サイクル疲れ破壊の傾向にあるC形拉よび両者の中間の破 壊形式を示す B 形の 3 種類に区別されることが確かめられた。

\section{4 考察}

試験片の最小断面における局部塑珄ひずみと繰返し数との関係はFig. 3〜Fig. 5 に示したようにサイクリック クリープ曲線となる。この曲線の勾配がクリープ速度 $d \bar{\varepsilon} / d N$ を与える。そこで破断位置である切欠き底に打沙 るクリープ曲線から中間期の定クリープ速度 $\Delta \bar{\varepsilon}_{m}$ を求める。著者らの一人は SM 41 および HT 60 の平滑試 験片および弾性応力集中率 2.16 の円孔試験片において上述の $\Delta \bar{\varepsilon}_{m}$ を縦軸に, 破断むでの繰返し数 $N_{f}$ を横軸 に両対数目盛りで図示寸ると両者の間には良好な直線関係が女り,

$$
\Delta \bar{\varepsilon}_{m} \cdot N_{f}=\bar{\varepsilon}_{0} / 2
$$

が成立することを示した1)。ただし $\bar{\varepsilon}_{0}$ は静的引張りにおける最大有効ひずみである。

そこで本報に打いても前報と同様にすべての試験片における切欠き底のサイクリック・クリープ曲線を描き, 中間期の勾配から定クリープ速度 $\Delta \bar{\varepsilon}_{m}$ を求め, $\Delta \bar{\varepsilon}_{m}$ と破断絽返し数 $N_{f}$ との関係を両対数目盛りで図示すると Fig. 14 をうる。ここでB形およびC形破壊を起こした試験片の $N_{f}$ は切欠き底にき裂が発生したときの繰返し 数である。同図中の実線は前報に括いて SM 41, HT 60 の平滑試験片および円孔切久き試験片 $(\alpha=2.16)$ 亿つい て求めた直線果積の法則を示したものである。また図中の A, B, C の記号は各試験片の破壞形式を区別するため 飞付したものである。本実験で用いた準棈円孔切欠き試験片および円孔切欠き試験片の弾性応力集中率は前者で 3.10, 後者で 2.42 であり, 前報の円孔切欠き試験片のそれに比べて大となつているけれども, Fig. 14 に示す ようにA形破壊を起こした試験片に関してはその切欠き形状, 寸法拉よび材質によらず定クリープ速度 $\Delta \bar{\varepsilon}_{m}$ と破 断綝返し数 $N_{f}$ との間には(1)式の関係が成立する。しかしC形破壊を起こした場合はいずれの試験片に㧍いて も (1)式の関係が成立せず眓中の実線からはずれて短寿命側に明らかに移行している。またB形破壞を起こした HT 60 の試験片による実験点は明らかに（1）式の直線から離礼て A 形と C 形破壊の中間に位置し低サイクル疲 


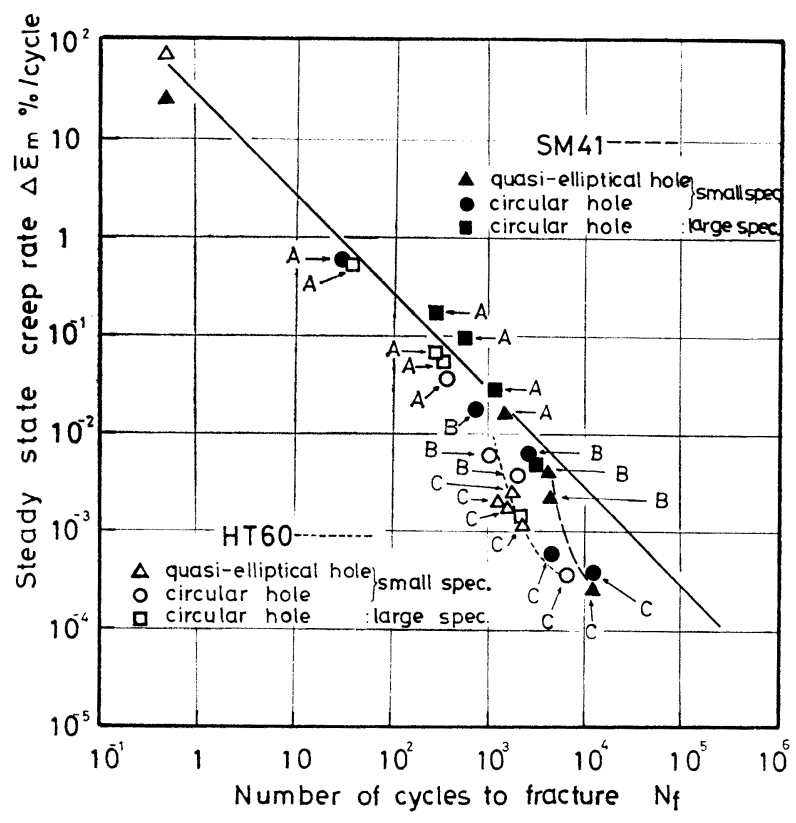

Fig. 14 Steady state creep rate vs. fatigue life

れから高サイクル疲れに遷移する領域にあ ると考えられる。しかしB形破壊を生じた SM 41 の場合はほぼ（1）式で近似できる ようである。したがつて（1 式で示される ような直線累積の法則が成立するのは応力 振幅が比較的高く延性破壊を起こす場合 で, 疲れき裂が発生, 伝播するよらな場合 は(1)式の直線からはずれて高サイクル疲 れに移行するよらになる。その臨界の繰返 し数はHT 60 よりも SM 41 において大 であり, 試験片の切欠き形状, 寸法によら ず HT 60 に対しては $10^{3}$ 回, SM 41 に対

しては $5 \times 10^{3}$ 回程度である。

\section{5 結言}

以上軟鋼おょび高張力鋼の準楕円孔切欠 き試験片および円孔切欠き試験片について 荷重制御低サイクル片振り引張疲れ試験を 行ない，モアレ縞により局部塑性ひずみを 解析して次の結論を得た。

（1）低サイクル疲れに拉ける破壞過程は切欠き底の断面全体に局部収縮を生じ静的破壊と類似の延性破壊を 起こすA形，切欠き底に括いて局部収縮を生じたのち疲れき裂を発生するがその後のき裂の進展は少なく，き裂 先端のひずみが急速に増加するB形，および切欠き底に拈いて疲れき裂が発生しひずみの増加を伴ならことなく 伝播するC形の 3 種類に区別される。

（2）切欠き底における最大有効ひずみはA形破壊の場合試験片の切欠き形状，寸法，材質のことなるいずれ の試験片においても50ないし60\%に達しており破断までの繰返し数には関係なく一定である。またC形破壞を 起こす場合はいずれの試験片においても疲れき裂発生位置の最大有効ひずみは $20 \%$ 以下である。B形破壞にお゙ けるとれはA形とC形の中間の值をとる。

（3）A形破壊を起こす場合は定クリープ速度 $\Delta \bar{\varepsilon}_{m}$ と破断までの繰返し数 $N_{f}$ との間に試験片の切欠き形 状, 寸法および材質には無関係に直線累積の法則が成立する。しかし疲れき裂が発生, 伝播して破壊する場合に は(1)式の関係は成立せず短寿命側に移行する。

（4）（1）式が成立する臨界の繰返し数は高張力鋼にお汭るよりも軟鋼の泣らが大きく, 試験片の形状, 寸法 によらず前者では $10^{3}$ 回, 後者では $5 \times 10^{3}$ 回程度である。

謝 辞

本研究に対して溶接学会疲労強度研究委員会の委員各位から種々有益なご意見をいただいた。また，本実験を 行ならにあたり井坂昌史君の労を多とするとともに本実験は昭和 44 年度文部省科学研究費の一部によつて行な われたことを付記し感謝の意を表する。

\section{参 考 文 献}

1）永井欣一，大塚昭夫，小川量也：“低サイクル片張り引張疲れに抢ける鋼材の望性ひずみ挙動”, 日本造船 学会論文集, Vol. 124 (1968) p.355 374

2）西田正孝: “灾力集中”, 初版, 森北出版 (1967), p.258～262， p.377～379 